\title{
A MANUAL OF GEOLOGY \\ FOR CIVIL ENGINEERS
}


This page is intentionally left blank 


\section{A Manual of}

\section{Geology for Civil Engineers}

\section{JOHN PITTS}

Nanyang Technological Institute, Singapore

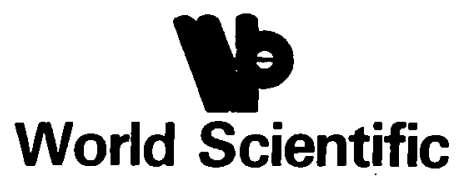




\section{Published by}

World Scientific Publishing Co. Pte. Ltd.

P. O. Box 128, Farrer Road, Singapore 9128

\section{A MANUAL OF GEOLOGY FOR CIVIL ENGINEERS \\ Copyright (C) 1984 by World Scientific Publishing Co Pte Ltd. \\ All rights reserved. This book, or parts thereof, may not be reproduced in any form or by any means, electronic or mechanical, including photo- copying, recording or any information storage and retrieval system now known or to be invented, without written permission from the Publisher.}

ISBN 9971-978-05-9

9971-978-12-1 pbk

Printed in Singapore by Singapore National Printers (Pte) Ltd. 


\section{PREFACE}

This manual of geology has been developed over a decade of teaching geology and engineering geology to undergraduate civil engineering students in the United Kingdom and Singapore. During that time, the course has changed dramatically, and I hope has improved so that it now meets the requirements of students aspiring to become professional civil engineers. One major lesson which has been learned over that decade is that students are more interested in subjects which they find relevant to their chosen vocation. It has therefore been essential to couch geology in terms suitable for civil engineers and deal with topics in geology immediately applicable to their needs. Many aspects of geology of a more esoteric nature are indeed fascinating, but within the time constraints of most civil engineering courses would probably be an unaffordable luxury.

As well as attempting to serve the needs of undergraduate civil engineering students, the aim has also been to put sufficient information in the book for it to serve as a useful handbook of geology for qualified civil engineers. To this end, geological methods employed in current civil engineering practice have been covered in some detail. This information should provide a sound base for geology to be used as a kind of materials science for geotechnics. Without some understanding of the geological make-up of soils and rocks both in the mass and in sample form, soil mechanics and rock mechanics can never fully be appreciated.

The geological information required by civil engineers is however not the same all over the world. The raw materials of soils engineering in particular are very different in the northern latitudes from those in the tropics. Relatively little coverage has been given to tropical conditions in the past, a deficiency which this book tries to remedy.

I should like to thank Mr H Dutton and Dr T Cairney of the Department of Building and Civil Engineering, Liverpool Polytechnic, UK, and Professor C N Chen of the School of Civil and Structural Engineering at the Nanyang Technological Institute, Singapore for their encouragement, and for recognizing the importance of geological training for civil engineers.

Thanks are also due to Yeo Chin Soon for preparing the many illustrations in the book and Jamillah Sa'adon for typing the manuscript. 


\section{ACKNOWLEDGEMENTS}

The publisher and author would like to thank the following for permission to quote or modify copyright material (figure numbers refer to this publication, full citations can be found by consulting captions and references).

American Association of Geographers for Fig. 4.1; American Geophysical Union for Fig. 4.17; Edward Arnold (Publishers) Ltd. for Figs. 7.6, 7.7,7.8, 7.9, 7.13, 7.14; Butterworths for Table 5.2; W.H. Freeman and Company for Fig. 4.18; Geological Society of London for Figs. 1.3, $4.11,4.12,4.13,4.14,4.15,6.20,6.21,6.22,6.23,6.24,6.25,6.26,6.27$, 7.1, 7.2, 7.3; The Geologists' Association for Fig. 1.1; The Institution of Civil Engineers for Fig. 1.4; The Institution of Mining and Metallurgy for Figs. 2.22, 3.11, 3.12, 3.13, 3.14, 3.15, 3.16, 3.18, 7.10, 7.11, 7.15, 7.16, 7.17, 7.18, 7.19; International Association of Engineering Geology for Fig. 6.19; Longman for Figs. 4.2, 4.4; National Research Council of America for Figs. 4.16(a) to (j) inclusive; Norwegian Geotechnical Institute for Figs. 3.5, 3.17; The Open University for Figs. 6.1, 6.2, 6.3; Singapore Journal of Tropical Geography for Fig. 4.19. 


\section{CONTENTS}

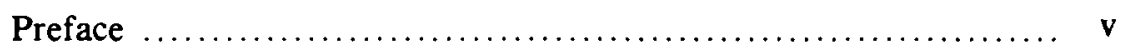

Chapter 1: BASIC CONCEPTS IN GEOLOGY AND THEIR RELEVANCE IN CIVIL ENGINEERING

$1.1 \quad$ Plate Tectonics ............................. 1

1.2 Uniformitarianism $\ldots \ldots \ldots \ldots \ldots \ldots \ldots \ldots \ldots, 2$

1.3 Superposition $\ldots \ldots \ldots \ldots \ldots \ldots \ldots \ldots \ldots \ldots \ldots, 2$

1.4 The Geochemical Cycle .................... 3

1.5 Geological Time and the Stratigraphic Column .... 4

1.6 Geomorphic Systems $\ldots \ldots \ldots \ldots \ldots \ldots \ldots \ldots . \ldots$

1.7 Thresholds and Uniformity of Natural Systems .... 6

1.8 Magnitude and Frequency of Forces in Geomorphic Processes ....................... 7

1.9 Equilibrium of Geological Processes and their Disturbance by Engineering Activity ........... 10

Chapter 2: ROCKS, THEIR COMPOSITION, IDENTIFICATION AND PROPERTIES

$2.1 \quad$ Igneous Rocks $\ldots \ldots \ldots \ldots \ldots \ldots \ldots \ldots \ldots \ldots, 17$

1 Classification of igneous rocks .............. 21

2 Control over the form of igneous rocks ........ 23

Volcanics ............................. 23

Intrusives $\ldots \ldots \ldots \ldots \ldots \ldots \ldots \ldots \ldots \ldots \ldots \ldots, 24$

2.2 Sedimentary Rocks $\ldots \ldots \ldots \ldots \ldots \ldots \ldots \ldots \ldots, 24$

1 Sedimentation $\ldots \ldots \ldots \ldots \ldots \ldots \ldots \ldots \ldots \ldots \ldots \ldots \ldots, 26$

$z$ Sedimentary facies $\ldots \ldots \ldots \ldots \ldots \ldots \ldots \ldots, 27$

3 Diagenesis ............................ 27

4 Diagenetic effects $\ldots \ldots \ldots \ldots \ldots \ldots \ldots \ldots \ldots, 28$

2.3 Sandstones ............................... 29

1 Distinguishing features of sandstones ......... 29

2 Classification of sandstones .................. 30

3 Clean sandstones $\ldots \ldots \ldots \ldots \ldots \ldots \ldots \ldots \ldots, 30$

4 Dirty sandstones $\ldots \ldots \ldots \ldots \ldots \ldots \ldots \ldots \ldots, 31$

5 Feldspathic sandstones ..................... 31

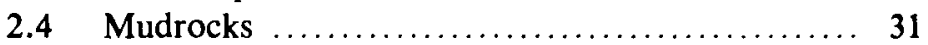


2.5 Carbonate Rocks ......................... 32

1 Terminology and classification of carbonate rocks .................................. 32

2.6 Metamorphic Rocks $\ldots \ldots \ldots \ldots \ldots \ldots \ldots \ldots \ldots, 33$

2.7 Classification of Rocks .................... 36

1 The use of feldspars in rock classification ..... 36 Igneous rocks ............................ 36

Metamorphic rocks $\ldots \ldots \ldots \ldots \ldots \ldots \ldots \ldots, \quad 36$

Sedimentary rocks ....................... 37

$2.8 \quad$ Identification of Rocks .................... 37

1 Identification of igneous rocks ................ 39

2 Identification of sedimentary rocks ........... 43

3 Identification of metamorphic rocks ......... 48

2.9 Some Engineering Properties of Rocks .......... 51

2.10 Elastic Properties of Rocks .................. 51

1 Moduli of elasticity ..................... 53

2 Geological influences on the elastic behaviour of rocks .................................. 55

3 Poisson's ratio ........................... 57

2.11 Strength Properties of Rocks ............... 58

1 Factors controlling the strength of rocks ...... 58

2.12 The Development of Index Properties of Rocks .... 60

Chapter 3: THE GEOMETRY, DESCRIPTION AND PROPERTIES OF ROCK MASSES

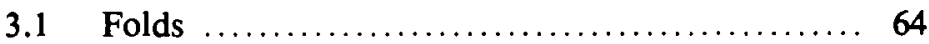

1 Geometry of folding $\ldots \ldots \ldots \ldots \ldots \ldots \ldots, 64$

3.2 Structural Discontinuities .................... 67

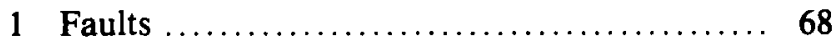

2 Rock cleavage $\ldots \ldots \ldots \ldots \ldots \ldots \ldots \ldots \ldots, 71$

3 Joints ............................... 72

4 Unconformities ......................... 73

3.3 Shear Strength of Discontinuities .............. 73

1 Influence of surface roughness on shear strength ............................... 74

2 Shear strength along actual joints ........... 76

3 Determination of $i \ldots \ldots \ldots \ldots \ldots \ldots \ldots \ldots, 77$

4 Apparent cohesion due to surface roughness ... 78

5 Peak and residual strength .................. 79

6 Shear strength of filled discontinuities ........ 80

3.4 Residual Stress ............................. 83

1 Gravitational stresses $\ldots \ldots \ldots \ldots \ldots \ldots \ldots \ldots, 83$

2 Latent stresses ............................. 84

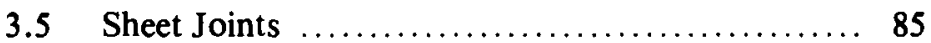


Chapter 4: WEATHERING, EROSION, TRANSPORTATION AND DEPOSITION

4.1 Weathering and its Significance in Geotechnical Engineering $\ldots \ldots \ldots \ldots \ldots \ldots \ldots \ldots \ldots \ldots \ldots, 86$

1 Weathering processes $\ldots \ldots \ldots \ldots \ldots \ldots \ldots \ldots 86$

2 Weathering and weatherability $\ldots \ldots \ldots \ldots \ldots, 86$

3 Weathering in humid tropical climate ....... 92

4 Tests to assess weatherability ............. 103

4.2 Engineering Classification of Weathered Rock .... 103

4.3 Erosion $\ldots \ldots \ldots \ldots \ldots \ldots \ldots \ldots \ldots \ldots \ldots \ldots \ldots \ldots \ldots$

Chapter 5: SOIL PARTICLES, SOIL FABRICS AND SOIL STRUCTURES

$5.1 \quad$ Non-cohesive Particles .................... 124

5.2 Cohesive Particles ....................... 125

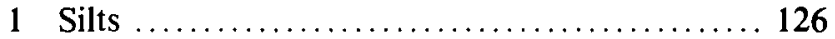

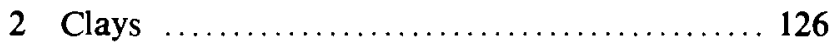

5.3 Clay Fabrics ............................... 129

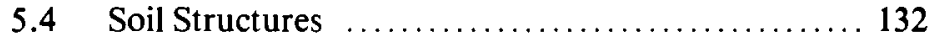

5.5 The Description of Engineering Soils ........... 135

Chapter 6: GEOLOGICAL AND GEOTECHNICAL MAPS

6.1 Geological Maps and Strike Lines ............ 137

6.2 Three Point Problems ....................... 158

6.3 Interpretation of Geological Maps $\ldots \ldots \ldots \ldots \ldots 163$

6.4 Geotechnical Mapping $\ldots \ldots \ldots \ldots \ldots \ldots \ldots \ldots \ldots$

1 Stratigraphical mapping $\ldots \ldots \ldots \ldots \ldots \ldots \ldots 171$

2 Structural mapping ..................... 171

3 Geomorphological mapping ............... 171

4 Hydrogeological mapping $\ldots \ldots \ldots \ldots \ldots \ldots \ldots 171$

5 Geomechanical mapping $\ldots \ldots \ldots \ldots \ldots \ldots \ldots 172$

6 Mapping the effects of man ............... 172

Chapter 7: LOGGING ROCK FOR ENGINEERING PURPOSES

$7.1 \quad$ Logging of Rock Cores .................. 181

1 General requirements of a borehole $\log \ldots \ldots \ldots 181$

2 Information to be recorded ................. 181

3 Information to be recorded on the borehole log 182

4 State of recovery of core .................. 183

7.2 Descriptive Geology ....................... 184

7.3 The Description of Rock Masses for Engineering Purposes .................................. 185

1 Rock material description ................... 185

2 Rock material indices ...................... 187

3 Rock mass indices ....................... 188 
7.4 Discontinuities .......................... 190

1 Weathering and altered state ............... 191

2 Discontinuity spacing in three dimensions ..... 191

7.5 Techniques for Carrying Out Classification Tests .. 194

7.6 Techniques for Obtaining Data ................. 194

1 Observations .............................. 194

2 Discontinuity surveys .................... 194

3 Recording and presentation of data ......... 195

7.7 Processing Discontinuity Data ............... 196

References ......................................... 207

Index $\ldots \ldots \ldots \ldots \ldots \ldots \ldots \ldots \ldots \ldots \ldots \ldots \ldots \ldots \ldots \ldots \ldots \ldots \ldots \ldots \ldots \ldots \ldots, 211$ 